\title{
Mīrzā Abūlqāsem Astarābādī-Fendereskī, Ḥasan Jamšīdī. Resāle-ye seneāiyye. Edition du texte, introduction et notes par Ḥasan Jamšīi $\mathbf{i}$
}

Mathieu Terrier

\section{(2) OpenEdition \\ 1 Journals}

\section{Édition électronique}

URL : http://journals.openedition.org/abstractairanica/40528

DOI : 10.4000/abstractairanica.40528

ISSN : 1961-960X

Éditeur :

CNRS (UMR 7528 Mondes iraniens et indiens), Éditions de l'IFRI

\section{Édition imprimée}

Date de publication : 1 décembre 2013

ISSN : 0240-8910

Référence électronique

Mathieu Terrier, « Mīrzā Abūlqāsem Astarābādî-Fendereskī, Hasan Jamšīdī. Resāle-ye șenāiyye. Edition du texte, introduction et notes par Hasan Jamšĩd̄ », Abstracta Iranica [En ligne], Volume 32-33 | 2013, document 385, mis en ligne le 01 juillet 2016, consulté le 05 octobre 2020. URL : http:// journals.openedition.org/abstractairanica/40528; DOI : https://doi.org/10.4000/abstractairanica. 40528

Ce document a été généré automatiquement le 5 octobre 2020.

Tous droits réservés 


\title{
Mīrzā Abūlqāsem Astarābādī- Fendereskī, Hasan Jamšīìi. Resāle-ye șenāiyye. Edition du texte, introduction et notes par Hasan Jamšì
}

\author{
Mathieu Terrier
}

\section{RÉFÉRENCE}

Mīrzā Abūlqāsem Astarābādī-Fendereskī, Ḥasan Jamšīīi. Resāle-ye șenāiyye. Edition du texte, introduction et notes par Ḥasan Jamšīdī, Qom, Bustān-e ketāb, 1387/[2008], 244 p.

Présentée par Henry Corbin dans La philosophie iranienne islamique aux XVII et XVIII siècles (Paris, Buchet/Chastel, 1981, p. 33-36), cette épître en persan du philosophe Mīr Fendereskī (m. 1050/1640-41), dont le titre peut être traduit par le «Traité des arts et activités humaines", nous paraît ici dans une édition critique établie à partir de plusieurs manuscrits. On déplore d'autant plus que des défauts d'impression rendent l'introduction partiellement illisible. Ce texte témoigne à la fois du classicisme péripatéticien et de l'éclectisme d'un des grands penseurs de la Renaissance safavide. Mīr Fendereskī conçoit d'emblée la Cité comme une unité organique exigeant que chacun de ses membres exerce une activité différenciée. Deux divisions des activités humaines sont successivement envisagées. Suivant une perspective morale, il oppose deux activités dont l'objet est universel et la recherche à la fois théorique et pratique : la première, au but sain, rassemble les prophètes, les imams, les philosophes et les mojtahedin; la seconde, dont le but est corrompu, comprend les athées, les hérétiques, les sophistes et les soufis antinomistes. L'A. distingue et articule les fonctions du prophète et du philosophe, conférant à celui-ci la supériorité sur le théologien (motakallem). À l'encontre des licencieux incorrigibles, il va jusqu'à prôner l'élimination 
physique. La seconde hiérarchie est métaphysique, ordonnée au système de l'être. Elle part du métier du forgeron, qui est comme la matière première (hayulā) de tous les autres arts, pour aboutir à l'activité du prophète, du calife et du philosophe, qui parachève l'œuvre de la nature. Dans la division des degrés de l'être, le néant pur se voit homologuer de surprenante manière à l'Ahriman du zoroastrisme. Derrière un syncrétisme un peu confus, cette œuvre exprime un effort de renouvellement de la falsafe péripatéticienne, une conviction profonde de l'accord entre raison philosophique et sagesse prophétique, ainsi qu'une familiarité réelle avec les doctrines des Grecs et des Indiens, le tout dans une langue persane ouvragée, émaillée de citations poétiques.

\section{AUTEURS}

\section{MATHIEU TERRIER}

Paris 